\title{
Effect of Foliar Application of Micro Nutrients on Growth and Flowering Characters of Gladiolus (Gladiolus grandiflorus L.) CV. Novalux
}

\author{
Aishwarya Mishra ${ }^{1}$, A.K. Singh ${ }^{1}$, Abhinav Kumar ${ }^{1 *}$ and Archana Singh ${ }^{2}$ \\ ${ }^{1}$ Department of Floriculture and Landscape, Collage of Horticulture and Forestry, Narendra \\ Deva University of Agriculture and Technology, Faizabad-224229 (U.P.), India \\ ${ }^{2}$ Krishi Vigyan Kendra, Masodha, Faizabad, Narendra Deva University of Agriculture and \\ Technology, Faizabad-224229 (U.P.), India \\ *Corresponding author
}

\begin{abstract}
A B S T R A C T
Keywords

Gladiolus, Micro nutrients (Fe and $\mathrm{Zn}$ ), Foliar application, 3rd and 6th leaf stage

Article Info

Accepted: 04 May 2018 Available Online: 10 June 2018

An experiment was carried out to study the effect of foliar application of micro nutrients on growth, flowering characters of gladiolus (Gladiolus grandiflorus L.) cv. Novalux in the year 2015-2016.The experiment was conducted in Randomized Block Design with nine treatments $\mathrm{FeSO}_{4} 0.25 \%, \mathrm{FeSO}_{4} 0.5 \%, \mathrm{ZnSO}_{4} 0.25 \%, \mathrm{ZnSO}_{4} 0.5 \%, \mathrm{FeSO}_{4} 0.25 \%+$ $\mathrm{ZnSO}_{4} 0.25 \%, \mathrm{FeSO}_{4} 0.25 \%+\mathrm{ZnSO}_{4} 0.5 \%, \mathrm{FeSO}_{4} 0.5 \%+\mathrm{ZnSO}_{4} 0.25 \%, \mathrm{FeSO}_{4} 0.5 \%+$ $\mathrm{ZnSO}_{4} 0.5 \%$ and a control replicated thrice to assess the effect of iron and zinc on growth and flowering characters of gladiolus. Result reveals that the spraying of $\mathrm{FeSO}_{4} 0.5 \%+$ $\mathrm{ZnSO}_{4} 0.25 \%$ was proved to be most effective to increase Plant height $(64.80 \mathrm{~cm})$, number of leaves per plant (9.26), number of days taken for spike initiation (98.53), number of days taken for opening of first floret (111.60), duration of flowering (15.10 days), length of spike $(103.40 \mathrm{~cm})$, Number of spike per ha $(1.35 \mathrm{lakh})$ and however, diameter of spike $(1.53 \mathrm{~cm})$ was recorded maximum in $\mathrm{FeSO}_{4} 0.5 \%+\mathrm{ZnSO}_{4} 0.5 \%$.
\end{abstract}

\section{Introduction}

Gladiolus (Gladiolus grandiflorus L.) is a bulbous ornamental plant which belongs to family Iridiaceae and sub family Ixiodeae, is native to tropical South Africa. Its ancestral chromosome number is 15 (Goldblatt et al., 1993). It is the most important bulbous flower of India and it is next to tulip in Holland and other countries. Gladiolus is popularly known as Queen of bulbous flower because of attractive spike, having florets of huge forms, dazzling colours and longer keeping quality and has been rated second popular flower in the world. The herbaceous plants sprouts from axillary buds of an underground structure, the corm is a condensed vertical root stock, covered with dried leaf base. It differs from a bulb being solid and having no stem. The gladiolus belongs to the genus Gladiolus which consists of more than 250 species. Its cultivation dates back to 1863 in India. Mr. Charles Gray of Connor was the person to grow gladiolus in India during the 19th century. It is a tender herbaceous perennial flower which can be successfully grown up to an altitude of $2400 \mathrm{M}$. Zinc, as a micronutrient, had undoubtedly attracted 
maximum amount of attention since early 1960 's. It is indispensable for proper growth and development of plants. Zinc is effective in plant nutrition for the synthesis of plant hormones and balancing intake of $\mathrm{P}$ and $\mathrm{K}$ inside the plant cells. It is important as a component of enzymes for protein synthesis and energy production and maintains the structural integrity of bio-membranes. Zinc plays an important role in seed development and zinc-deficient plants show delayed maturity. Zinc is required for the synthesis of auxin IAA and for carbohydrate metabolism, protein synthesis, internode elongation for stem growth, pollen formation. $\mathrm{Zn}^{2+}$ ions at low concentration $(0.01 \mathrm{ppm})$ slightly enhance the activity of tryptophan synthesis leading to biosynthesis of auxin.

Iron act as catalyst in synthesis of chlorophyll molecule and helps in the absorption of other elements. It is a key element in various redox reactions of respiration, photosynthesis and reduction of nitrates and sulphates. Iron deficiency is common in alkaline soil with typical chlorosis; the young leaves turning yellowish with veins remaining green. Iron application increased the levels of all leaf pigments, but the extent of increase in level depend on the pigment affected. So the use of $\mathrm{Fe}$ and $\mathrm{Zn}$ individually or in proper combination of these two micronutrients can exhibit major role in production of vigorous plants having maximum number of leaves and shoots which have a positive response on quality flower production.

\section{Materials and Methods}

The present study was undertaken at Main Experimental Station, Horticulture, N.D. University of Agriculture and Technology, Kumarganj, Faizabad (U.P.) during the winter season of the year 2015-16. Geographically, it is situated in subtropical zone of eastern U.P. at 26.47 $\mathrm{N}$ latitude, 88.12 E longitudes and at an altitude of 113 meter from mean sea level. The experiment was laid out in Randomized Block Design (RBD) with nine treatments either alone or in combination of zinc and Iron replication thrice to evaluate the effect on growth and flowering of Gladiolus. The corms of Novalux variety was sown at $40 \times 20 \mathrm{~cm}$ spacing in a well prepared field in the month of October. The foliar application of micro nutrients viz. Zinc and Iron were applied at 3 leaf and 6 leaf stage. Nitrogen and phosphorus were applied in the form of urea and single superphosphate. Urea was applied in two split doses as half amount as basal dose at the time of sowing of croms and half as top dressing 30 days after sowing, while phosphorus was applied in single dose with recommended dose of Muriate of Potash (MOP) at the time of final field preparation. Observations were recorded on vegetative characters at bud initiation stage and flowering attributes at different stage of flowering. The data had been statistically analyzed adopting procedure as given by Fisher and Yates (1949).

\section{Results and Discussion}

The statistical analysis of data (Table 1) revealed that maximum plant height $(64.80$ $\mathrm{cm})$, number of leaves per plant $\left(9.26 \mathrm{~cm}^{2}\right)$, were obtained with treatment combination $\mathrm{FeSO}_{4} 0.5 \%+\mathrm{ZnSO}_{4} 0.25 \%$, the plant height was increased by the combination of $\mathrm{Zn}$ and Fe might due to the increased synthesis of auxin and utilization of carbohydrate in improving plant height. The micronutrients (Fe and $\mathrm{Zn}$ ) helps in cell division, cell multiplication and these micronutrients activate several enzymes and physiological activities resulting in an increased plant growth and development through overall promotion of growth parameters like number of leaves per plant. The findings are in conformity with reports made by Halder et al., (2007), Mir et al., (2007), Kakade et al., (2009) in gladiolus. 
Table.1 Effect of foliar application of micro nutrients on growth and flowering characters of Gladiolus (Gladiolus grandiflorus L.) cv. Novalux

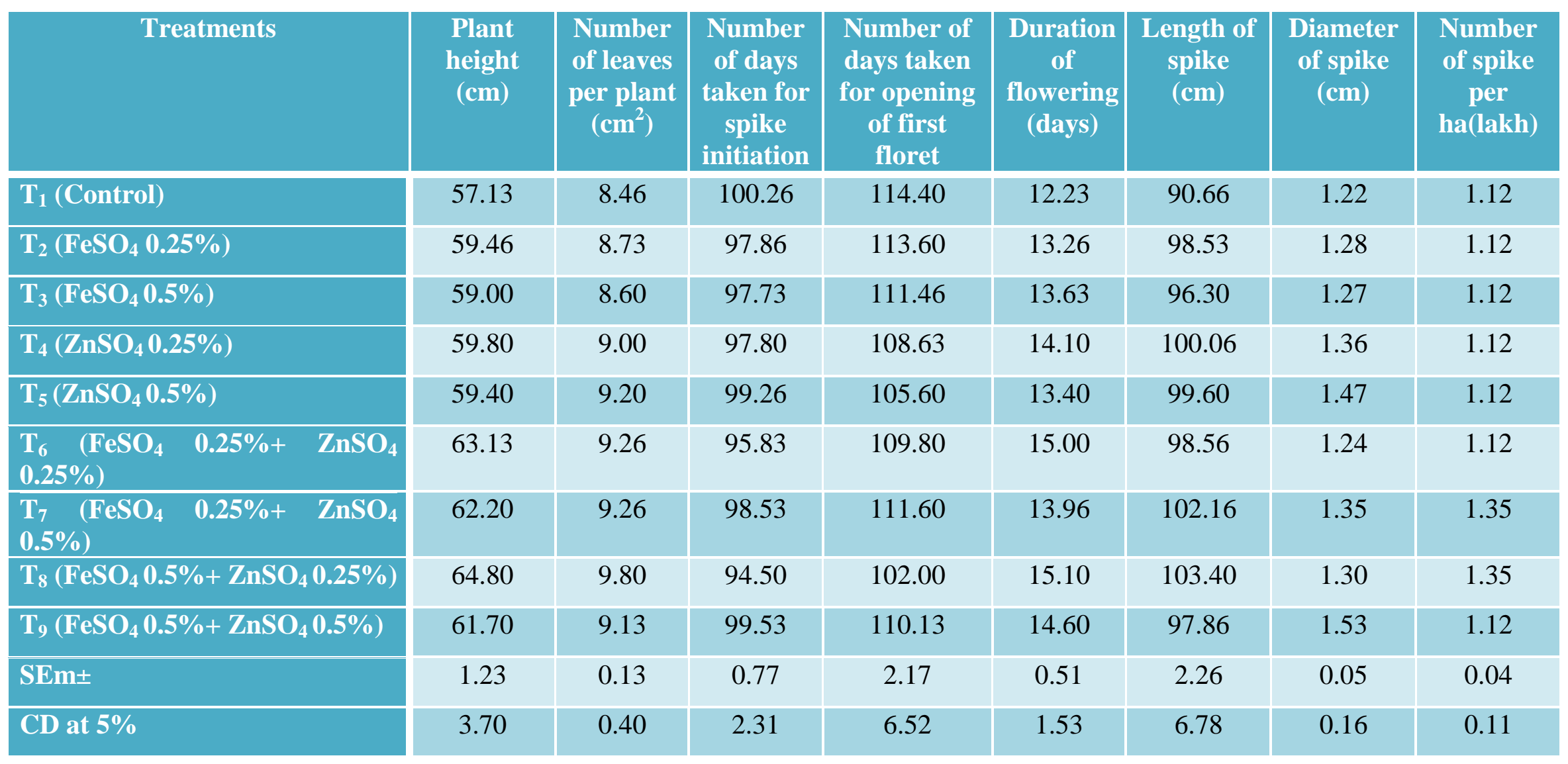


The days taken for spike initiation (94.50 days) and opening of first floret (102.00 days) were recorded earliest with the spraying of $\mathrm{FeSO}_{4} \quad 0.5 \%+\mathrm{ZnSO}_{4} \quad 0.25 \%$. This reduction in number of days to spike emergence might be due to $\mathrm{Zn}$ and $\mathrm{Fe}$ because these micronutrients are quite effective in reducing the juvenile period of plants and favours storage of more carbohydrates through photosynthesis, which might be the reason for earlier spike initiation. Similar findings were made by Chattopadhayay et al., (2001) and Mir et al., (2007) in carnation.

Duration of flowering (15.10 days) was recorded maximum with $\mathrm{FeSO}_{4} 0.5 \%+\mathrm{ZnSO}_{4}$ $0.25 \%$. This might be due to an early and enhanced growth by $\mathrm{Zn}$ and $\mathrm{Fe}$ and also might be due to increased efficiency of physiological activities of plant by $\mathrm{Zn}$ and $\mathrm{Fe}$ treated plants with respect to synthesis of metabolites as per the findings of Mir et al., (2007) in carnation.

Length of spike $(103.40 \mathrm{~cm})$ and number of spike per hac. (1.35lakh) was recorded maximum with $\mathrm{FeSO}_{4} 0.5 \%+\mathrm{ZnSO}_{4} 0.25 \%$. The differences in the response of micronutrients with respect to spike length might be due to the fact that these nutrients (Fe and $\mathrm{Zn}$ ) activate several enzymes (catalase, peroxides, alcohol dehydrogenase, carbonic dehydrogenase, tryptophan synthetic, etc.) and involve in chlorophyll synthesis and various physiological activities by which plant growth and development are encouraged. Similar observations were also reported by Kumar et al., (2004) in tuberose and Chopde et al., (2015) in gladiolus.

Diameter of spike $(1.53 \mathrm{~cm})$ was recorded maximum with $\mathrm{FeSO}_{4} 0.5 \%+\mathrm{ZnSO}_{4} 0.5 \%$. The greater thickness of spike might be due to $\mathrm{Fe}$ and $\mathrm{Zn}$ because introduces produce more food material which subsequently increased in the quality parameters, they also help in cell division and multiplication and enhance some physiological processes which are helpful to increase diameter of spike. Similar result was also reported by Ahmad et al., (2010) in rose.

\section{References}

Ahmad, I., Khan, M.A., Qasim, M., Ahmad R. and Randhawa, M.A., 2010. Growth, yield and quality of Rosa hybrida L. as influenced by various micronutrients. Pakistan Journal of Agricultural Sciences, 47(1): 5-12.

Chattopadhayay, M.K., Das, and T.K., 2001. Effect of foliar application of zinc, copper and iron on yield and quality of Gladiolus grandiflorus cv. Mirela. Journal of Interacademicia, 5(3): 300303.

Chopde, N., Nehare, N., Maske, S.R., Lokhande, S. and Bhut, P.N., 2015. Effect of foliar application of zinc and iron on growth, yield and quality of gladiolus. Plant Archives, 15 (1): 417419.

Fisher, R.D. and Yates, F. (1949). Statistical table for biological and medical research, oliver and boyd. Edbery (Londan) $: 3^{\text {rd }}$ edition.

Goldbatt, P., Takii, M. and Razzaq, Z.A., 1993. Chromosome cytology in tropical African Gladiolus. Annals of Missuor Botanical Garden, 80 (2): 461-470.

Halder, N.K., Ahmed. R., Sharifuzzaman. S.M., Anzu-Man-AraBagam and Siddiky, M.A., 2007. Boron and zinc fertilization on corm and cormel production of gladiolus terrace soils of Bangladesh. International Journal of Sustainable Crop Production, 2 (5): 8589.

Kakade, D.K., Rajput, S.G. and Joshi, K.L., 2009. Effect of foliar application of $\mathrm{Fe}$ and $\mathrm{Zn}$ on growth, flowering and Yield of China aster (Callistepus chinensis L. 
Nees). The Asian Journal of Mir, M.A., Singh, S. and Lone, R.A., 2007. Horticulture, 4(1): 138-140.

Kumar, J. and Singh, D., 2004. Post-harvest life of tuberose $\mathrm{Cv}$. Pearl Double spike as affected by $\mathrm{GA}_{3}$, NAA and sucrose Journal of Ornamental Horticulture, 7(2): 188-191. Effect of $\mathrm{Zn}$ on the growth and flowering of Carnation (Dianthus caryophyllus L.) cv. Chabound Red. The Asian Journal of Horticulture, 2(1): 147-148.

\section{How to cite this article:}

Aishwarya Mishra, A.K. Singh, Abhinav Kumar and Archana Singh. 2018. Effect of Foliar Application of Micro Nutrients on Growth and Flowering Characters of Gladiolus (Gladiolus grandiflorus L.) CV. Novalux. Int.J.Curr.Microbiol.App.Sci. 7(06): 662-666.

doi: https://doi.org/10.20546/ijcmas.2018.706.076 